Images in...

\title{
Lepromatous phlebitis of the left external jugular vein
}

Surinder Thakur, ${ }^{1}$ Guman Singh Negi, ${ }^{1}$ Irappa Madabhavi, ${ }^{1}$ Swaroop Revannasiddaiah ${ }^{2}$

${ }^{1}$ Internal Medicine Department, Indira Gandhi Medical College, Shimla, Himachal Pradesh, India;

${ }^{2}$ Radiation Therapy and Oncology Department, Regional Cancer Center, Shimla, India

Correspondence to Dr Swaroop Revannasiddaiah, swarooptheone@gmail.com

\section{DESCRIPTION}

A painless lump over the left lateral aspect of the neck was the sole presenting complaint of a 54-year-old gentleman.
On examination, the lump was cord-like, non-tender, nonpulsatile and mobile (figure 1). There were no other lumps or elsewhere in the body. Doppler ultrasonography of the

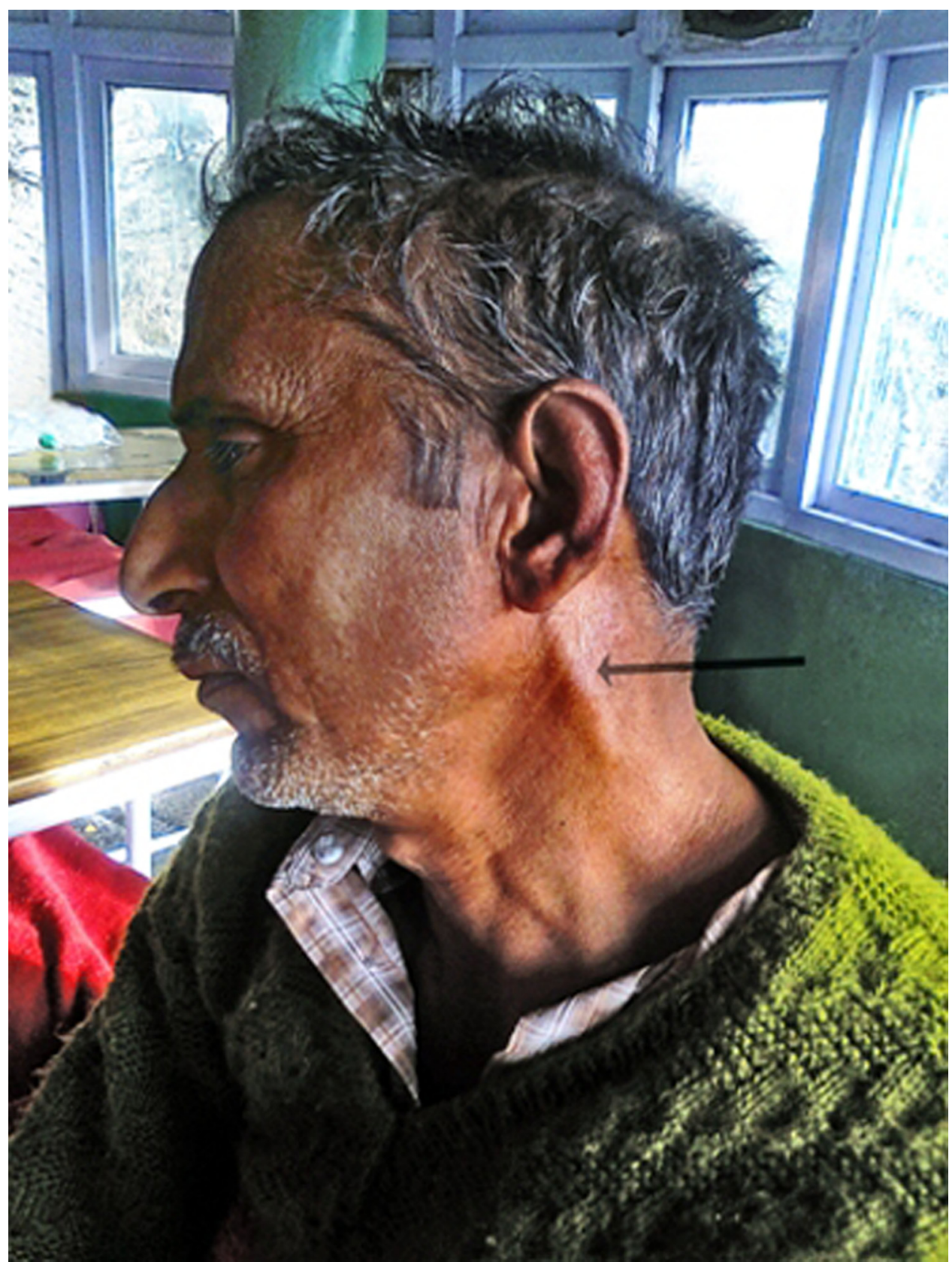

Figure 1 A mobile, non-pulsatile, non-tender lump over the left lateral aspect of the neck. 


\section{BMJ Case Reports}
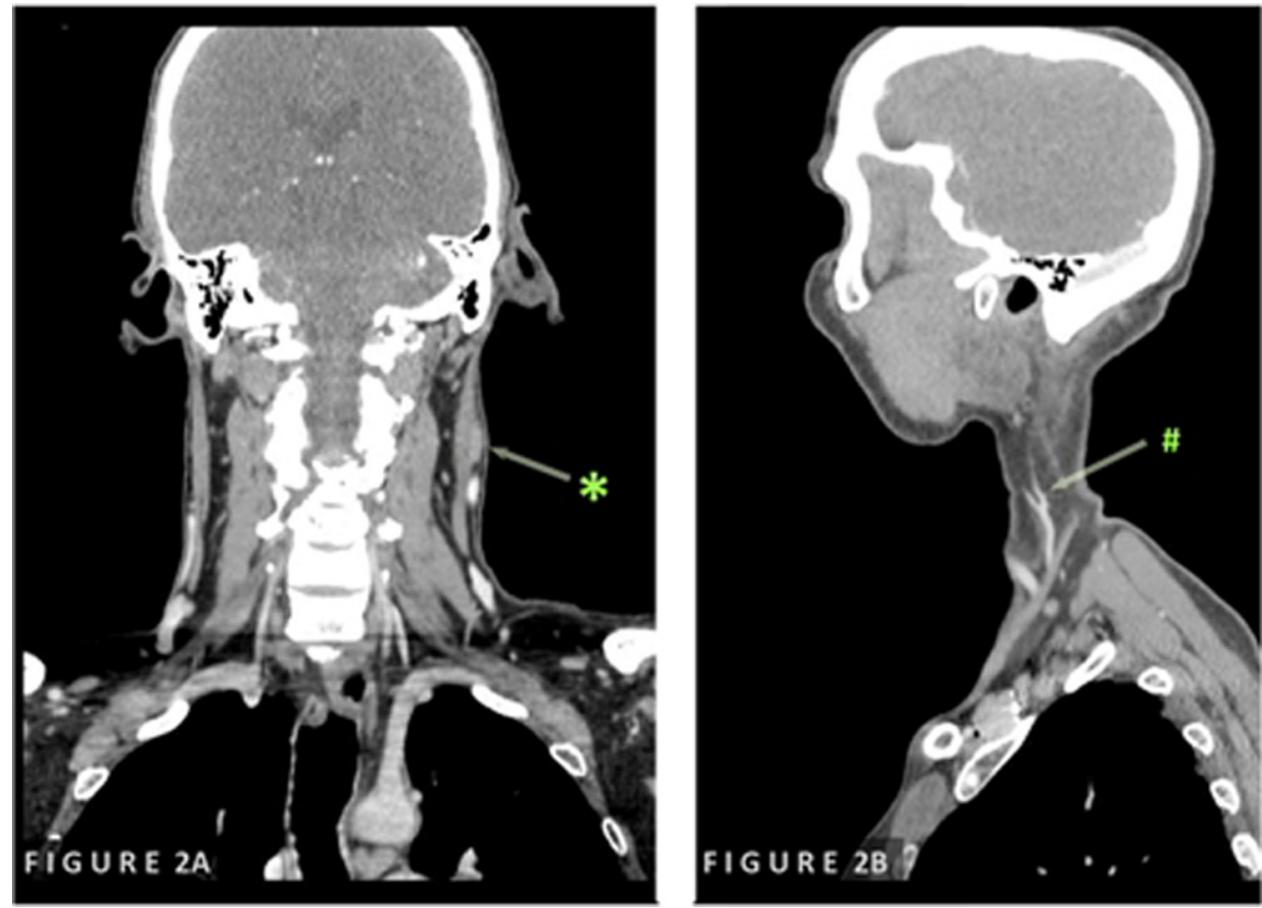

Figure 2 (A) The lesion $\left({ }^{*}\right)$ visualised on a coronal computed-tomography reconstruction. (B) An oblique-coronal plane reconstruction demonstrating absence of contrast enhancement of the left external jugular vein cranial to the level of obstruction (\#).

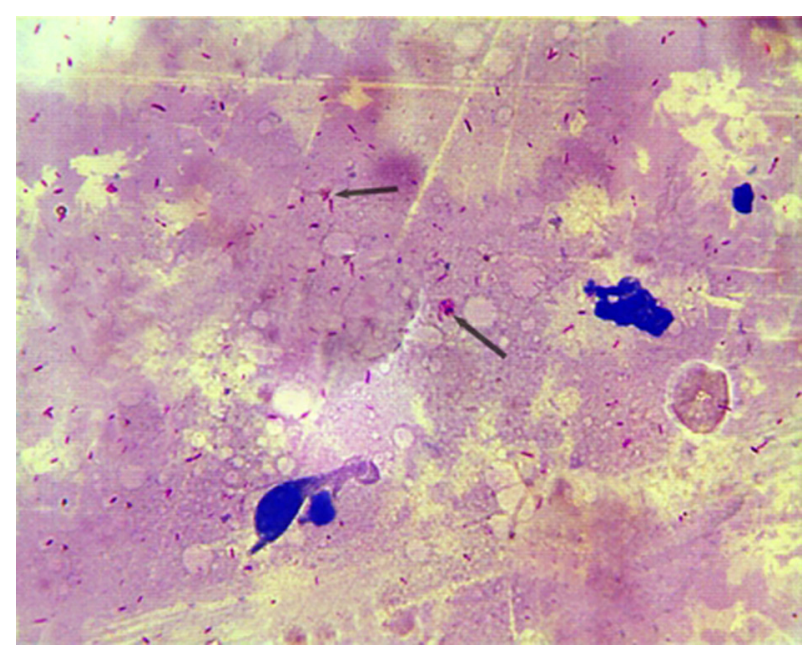

Figure 3 Zeihl-Neelsen staining of aspirate from the neck lump demonstrating numerous acid-fast bacilli, some of them arranged in globi (arrows).

neck was suggestive of left external jugular vein thrombosis. Contrast enhanced multi-detector CT imagery showed that the lump (figure 2A) was continuous inferiorly with the external jugular vein which was not patent above the level cranial to the lump (figure $2 \mathrm{~B}$ ). A fine needle aspiration cytology of the lump yielded a granulomatous aspirate. Zeihl-Neelsen staining of the aspirate showed acid fast bacilli, some of them arranged in clusters (globi) (figure 3). A careful clinical examination on the lines of leprosy revealed patchy areas of sensory loss over the face and the radial aspect of the left forearm. Slit-skin smears from these patches also were positive for acid fast bacilli. The diagnosis was hence established as leprosy (Hansen's disease). Leprosy is a disease known for a characteristic predilection towards two particular tissues- skin and nerves. Vascular involvement is rare and when present may be a part of disseminated disease in advanced cases. ${ }^{1}$ Lepromatous phlebitis of the external jugular vein as a presenting feature is an extremely rare occurrence, and a thorough literature search yielded only a single prior documented case. ${ }^{2}$ Lepromatous involvement of blood vessels is likely to be secondary to involvement of the nervi-vasorum of the blood vessels. ${ }^{3}$

\section{Competing interests None.}

Patient consent Obtained.

\section{REFERENCES}

1. Goulart LR, Goulart IM. Leprosy pathogenetic background: a review and lessons from other mycobacterial diseases. Arch Dermatol Res 2009;301:123-37.

2. Thompson AM, Lynn AA, Robson $K$, et al. Lepromatous phlebitis of the external jugular vein. J Am Acad Dermatol 2003;49:1180-2.

3. Mukherjee A, Misra RS, Sharma AK. Ultrastructure of leprous phlebitis. Int J Lepr Other Mycobact Dis 1985;53:571-6. 


\section{BMJ Case Reports}

This pdf has been created automatically from the final edited text and images.

Copyright 2012 BMJ Publishing Group. All rights reserved. For permission to reuse any of this content visit http://group.bmj.com/group/rights-licensing/permissions.

BMJ Case Report Fellows may re-use this article for personal use and teaching without any further permission.

Please cite this article as follows (you will need to access the article online to obtain the date of publication).

Thakur S, Negi GS, Madabhavi I, Revannasiddaiah S. Lepromatous phlebitis of the left external jugular vein. BMJ Case Reports 2012;

10.1136/bcr.01.2012.5473, Published XXX

Become a Fellow of BMJ Case Reports today and you can:

- Submit as many cases as you like

- Enjoy fast sympathetic peer review and rapid publication of accepted articles

- Access all the published articles

- Re-use any of the published material for personal use and teaching without further permission

For information on Institutional Fellowships contact consortiasales@bmjgroup.com

Visit casereports.bmj.com for more articles like this and to become a Fellow

Keep up to date with all published cases by signing up for an alert (all we need is your email address) http://casereports.bmj.com/cgi/alerts/etoc 